\title{
BSchools and Their Business Models
}

\author{
J. -C. Spender ${ }^{1}$
}

Received: 12 February 2016/Accepted: 25 November 2016/Published online: 17 January 2017

(C) The Author(s) 2017. This article is published with open access at Springerlink.com

\begin{abstract}
In 1937 Coase explored the 'nature of the firm' and concluded economists cannot explain why firms exist, why their boundaries are where they are, why their internal arrangements are as they are, or why their performance is so varied. Without a viable theory of the firm we educators have no sound basis for teaching managing them. Economists have not yet answered Coase's questions and our discipline seems to ignore the implications. More precisely we have no theories of the firm that can explain profit, yet surely our students are headed into managing profit-seeking? If we follow Knight's intuition and introduce uncertainty we create great difficulties for those managing business schools, as Simon observed in his 1967 paper on designing them (Simon, Journal of Management Studies, 4(1): 1-16, 1967). This essay explores the implications for business schools of seeing a firm as a local language that indicates what must be attended to and how that should be treated if value and profit is to be created.
\end{abstract}

Keywords Theory of the firm · Entrepreneurship · Business ethics · Value-creation

\section{The Current Model}

Looking at business schools around the globe we find considerable agreement about the format and content of business education. There is a 'business school model' - and it is global. Those who find fault with what we are doing think more in terms adjustment and refinement than of radical reconstruction (Carrington Crisp 2013; Datar, Garvin, and Cullen 2010; Durand and Dameron 2008; Fragueiro and Thomas 2011; GMAC 2013b; Hardy and Everett 2013; Jaiswal 2015; Lorange 2008; Morsing and Sauquet 2011; Muff et al. 2013; Peters and Gitsham 2009; Spender 2008; Spender and Khurana 2013) - though there are many critical voices too; Mintzberg, Locke, Starkey and others (Byrne 2013; Currie, Knights, and Starkey 2010; Grey 2004; Locke and Spender 2011; Mintzberg 2004, 2013; Parker 2002; Starkey and Tempest 2001; Starkey and Tiratsoo 2007). Even as the content and pedagogical emphasis

J. -C. Spender

jcspender@kozminski.edu.pl

1 Kozminski University, Warszawa, Poland 
may vary; quantitative analyses dominating while some schools use case teaching and others stress social responsibility over the pursuit of shareholder wealth, these are variations within a shared conceptual framework and discourse.

The education is also focused on the private sector. Business schools may be alike in many respects but clearly differ from schools of public administration, education, government, or politics. Business schools also presume the private firm is an unproblematic entity; Pandora, Peugeot, and posh restaurants exist, and are considered comparable rather than unique and incomparable. Firms may well be categorized according to size, employee numbers, market capitalization, geographic scope, and so on, but still be considered comparable. Even SMEs are presumed members of a larger population of comparable entities whether in Scotland, Spain, or New Zealand. The nature of the management task is likewise relatively unproblematic - data-informed direction and control to maximize performance towards strategic goals such as profit or market share. Again there are variations as some schools emphasize financial management, others the allocation of non-financial resources, others people-management, others international production and commerce. Some schools might look to managing in more complex social and political situations but still presume that their sustainability and corporate social responsibility targets are comparable to financial targets, computable and not of a different genus. In other words, a firm is a firm and managing is managing - a generic activity to be taught without reference to the contexts in which students should transform what they have learned into the private firm's archetypal profit-seeking practice.

There are huge administrative and pedagogical benefits to this questionable view. Students with various interests and orientations can be enrolled into the same courses. Faculty can be hired based on their disciplinary background rather than knowledge of managing's various contexts. Textbooks can be chosen based on their presentation of theory. When we look at engineering and medical schools we see something totally different. High voltage transmission differs from robotics and rocket science; just as dealing with Alzheimer's is not the same as arthroscopic surgery or treating infectious diseases. Students who get beyond these schools' introductory courses specialize, and most faculty members are specialists with close involvement with specialized practice. Of course business schools claim to be professional schools but the dimensions of the profession remain wholly mysterious (Khurana 2007; Spender 2005, 2007), and even though specialized management degrees are proliferating the core of our industry remains its MBA programs (AACSB 2013; GMAC 2013a).

\section{Theory, Practice, and Indexicality}

We can explore business schools and their educational objectives by paying attention to two matters. First, the much-discussed relationship between theory and practice. Second, the less examined distinction between generalities and particularities and the Peircian concept of 'indexicality' (Moore 1972; Scheffler 1974), the importance of grasping the 'here and now' of business (Hayek 1945). The first fuels an enormous literature of complaint about business schools and points to the contrast between the business schools' quantitative and theoretical discourse and its evident lack of relevance to practicing managers. There are surprisingly few business school research achievements we can point to that match the high impact of university-based scientific research into engineering or medical practice. Yet most business schools trumpet the importance of their research, paying less attention to their non-research aspects such as public service, or their students' managerial professionalization, job placement, 
or socialization. Theory-practice gap remedies are repeated routinely - ways to bring business people and/or their interests into the school's research programs to counter-balance the strong academic incentives to focus on methodological performance and its publication. One remedy might be to bring business people onto the school's Board of Trustees, or onto the administrative team that manages the school's research activities, whether that be fee-earning consultancy, long term strategic engagement with firms, student internships and business 'placements', with business-people in residence or as 'clinical faculty', or via thoughtful direction of doctoral programs towards the problems found in business practice rather than in the academic literature.

Several decades of discussion around these remedies has failed to produce much correction; the opposite seems to have occurred. The disparity between the problematics considered in the business schools' discourse, teaching, and publications and the concerns of practicing managers seems greater than ever, even though there have been important additions to the mainstream curriculum. Bok's 1978 analysis of Harvard Business School precipitated re-modeling the curriculum to include business ethics, now more or less mandated by the AACSB (Bok 1978). But his comments about the emphasis on quantitative methods and the lack of attention to the public sector has not led to any corresponding curriculum change. Corporate social responsibility and ecological sustainability have been added to many schools' curricula without doing anything to dilute the curriculum's quantitative core. After the 2008 financial collapse students' hunger for entrepreneurship courses brought it into many curricula without substantial theoretical foundation or greatly shifting their program's overall quantitative orientation. In short, the mainstream business school model has remained much the same over the last few decades - ensure the students get a good understanding of the theories developed in our field's principal branches - accounting, finance, economics, marketing, organizational theory, organizational behavior, strategy, operations, management science, IT, and MIS.

At the same time, we are not at all clear about what students are supposed to do with this learning, and here we seem at great variance from other professional schools, such as medicine or engineering. A professional school's students are generally faced with two modes of valuecreation; one theoretical, the other practical. Medical students can become researchers, maybe probing the nature of viruses with the possibility of a Nobel, or they can become practitioners, local physicians, surgical specialists, or major hospital department heads. Likewise, business school students can become researchers with publications and professorships in mind or they can become executives whether in SMEs or major corporations. In English language business schools the doctoral students are normally in the first category, being trained to join the faculty in our industry or serve as researchers and report writers in the many 'think tanks' that offer theoretically-sound economic advice to politicians and corporations (Spender and Khurana 2013). But what are MBAs being trained to do? Get jobs - of course - but to do what? Few faculty members understand what goes on in firms, what their ex-students do at Goldman Sachs or McKinsey.

We can also wonder about the complexities of the relationship between theory and practice. Is practice simply the implementation of theory? Does theory supply all the information and insight necessary to determine effective practice? The conventional MBA curriculum seems to suggest 'yes' - or a shrug of the shoulders with a 'who knows?' Academics might label the link between theory and desired practice the practical manager's 'theory of the firm' (ToF) - the practice of identifying and bringing appropriate data into the action context. Using practitioner language, this is also labeled the firm's 'business model' (Magretta 2002). We can wonder if there is a 'theory of the business model' that might displace the economist's more formal ToF. 
Many engineering and medical schools help their non-research oriented students develop practical expertise by exposing them to the complexities of professional practice and confirming that theory alone cannot ever provide all the answers. We can argue practice is always in the particular, the 'indexical' (to use Peirce's term), and that there is always a conceptual and methodological gap between the indexical and the general. Those with experience of practice's complexity find theory's inability to capture everything that seems to matter to effective practice startlingly obvious. Rather than practice being the rigorous implementation of deterministic theory, practice always calls for something beyond what even the best theory can provide. In short, there is an epistemological gap between what theory provides and what managers actually bring into mindful professional practice (Tsoukas and Mylonopoulos 2004). The gap arises from the difference between the generalities essential to the language of theorizing and the indexicalities of practice - the distinction between the idiographic and the nomothetic (Silverstein 1988). In a world of certainty, that normally presumed by neoclassical economists and systems theorists, this gap cannot arise. In such a world management - the rigorous allocation of knowable and unproblematic resources towards known goals - can be fully captured by theory. But the world practicing managers inhabit is characterized by pervasive uncertainty. In the background is Frank Knight and Ronald Coase's suggestion that without 'radical uncertainty' there would be neither firms nor an economy (Bewley 1998; Boudreaux and Holcombe 1989; Coase 1993; Coase and Wang 2012; Knight 1921). As uncertainty creates a situation that leads to both firms and economic value creating activity, it drives a gap between theory and practice, and bringing business people onto the faculty or Board of Trustees cannot ameliorate this. Business people can remind the school about the theory-practice gap but there is no reason they should be able to deal with it any better than the academics can.

How does mindful professional practice differ from rigorous theorizing? In a famous 1967 paper Herbert Simon described business schools as 'a problem in organization design' (Khurana and Spender 2012; Simon 1967). The paper is a bitter-sweet reflection on his own experience of setting up the management school at Carnegie Mellon (Spender 2013). It is much cited though many may miss its essence. Simon was educated into the pre-WW2 University of Chicago political science tradition, marked by multi-disciplinarity and the consequent need to engage human powers of synthesis when it comes to social, political, and economic action in the real world (Klein 1990). His use of Kant's distinction between analytic and synthetic propositions is seldom mentioned today. But Simon deployed it to specify what he felt was the fundamental challenge of designing and managing a business school. Business schools normally embrace a plethora of academic specializations so, left to their own devices, their academics gravitate towards their own disciplines and erect silos - for therein their scholarly and methodological investments have highest value and generate the highest dividends, given today's career shaping incentives to do so. Simon called this a move towards the 'equilibrium condition'. He pointed to the academic value-adding process as very different from business peoples' practical skill development and career advancement. Academics march to theory's drums, not to profit, wellness, or sustainable competitive advantage. Thought is their medium, not action. In contrast, economic activity is directed towards the creation of economic value, not scholarly contribution. Consequently, the school's leaders - the Dean and others - must push continually against the 'entropy' being created as the school's academics drifted towards the equilibrium condition, widening the rigor and relevance gap. Simon surmised the flaw in the business school's design lay in over-promoting the entropycreating processes and underplaying the constraints or correctives necessary to support the 
synthesizing managers must learn. Putting business people on the Board does little to help the Dean withstand the faculty's tendencies.

In short, a business school's model is flawed so long it fails to deal effectively with the conflicts created by pursuing two distinctly different kinds of value - on the one hand scholarly contribution, on the other training in economic value creation. Abandoning one or other is not within their charter. The tension comes with the educational territory chosen, presuming there is or should be a workable relationship between academic theory and business practice. The reputations of a university's other professional schools, such as engineering, medicine, law, architecture, dentistry, education, and so on also turn on how they manage this tension within their own mediums. Given this tension between thinking and doing is always present, even if seldom understood (Pfeffer and Sutton 2000), professional schools wax and wane continuously. The university's other professional schools generally perform better than its business school because they achieve a better balance between scholarly contribution and practical value creation. What can be done with the business school?

\section{Framing Possibilities}

Some might think a discussion about the 'theory of the firm' out-of-place here, but it can be used to point to the two different kinds of value creating evident in business schools. For some, especially micro economists, the term identifies an area of scholarly work that does not include strategizing or managerial practice. The economists' problematic is well framed by Coase's questions; why do firms exist, why are their boundaries where they are, why are their internal arrangements as they are, and why is their performance so varied? (Coase 1991) Micro economists have not yet answered these questions, raising questions about our understanding of the nature of managing as well as of the nature of the firm. Two kinds of answer are possible. First, that the economists have now answered Coase's questions using their own terms. Second, very different, that their answers are viable guides to better managerial practice. Considering the second answer first, under conditions of certainty theory is always sufficient to the practice, which drops out of the analysis in the sense that managerial practice is no more than the precise implementation of the theory of the firm (ToF). But under Knightian uncertainty the epistemological gap points to weakness or a breakdown in the ToF as a rigorous determinant of managers' practice. Most students are familiar with the handful of ToFs recently available; transaction cost analysis (TCA), principal-agent theory (PAT), team production, nexus of contracts, property rights, and so on (Demsetz 1988). When Coase died in 2013 many of his obituaries implied he had answered his own questions by 'inventing' transactions costs. Yet this was far from his own view (Medema 1995). As he argued throughout his life, a viable ToF would have to take account of the idiographics of transaction's legal and institutional context, there could be no universal or nomothetic theory. Most of the presentations of TCA and PAT presume the particulars have been accounted for. But, even in the economists' own terms, can the comparative costs of within-firm and within-market transactions ever be properly accounted? The most novice accountant knows the difference between marginal costs and fully allocated overheads. What are the overheads of any particular transaction and how might the corresponding 'overheads' of a market transaction - such as the cost of the legal apparatus necessary to establish and police title - be determined and allocated? Likewise Jensen \& Meckling's suggestion that there can be a formal solution to the principalagent 'problem' is simply a mistake (Spender 2011). 
In general, these micro economic ToFs only prescribe a solution when there is no Knightian uncertainty - they miss the manager's contribution entirely. For managers interested in valuecreation their ToF points to the indexical bridge between available theory and situated practice. Under uncertainty an appropriate ToF would be analogous to 'theories' of effective surgical or architectural practice. Knowing this as their pedagogical objective, schools of medicine and architecture try to give their students some understanding of how they must select from the more universal theories accepted by their profession and meld or synthesize them into an indexical answer - along with their personal cognitive and creative capabilities - especially their powers of observation. Barnard's description of the business executive - synthesizing the three sub-economies into the organization 'economy' - is precisely this; practice in an uncertain world (Barnard 1951). Medical and architectural faculty members never suggest theory alone is sufficient to the students' practice; that would be 'unprofessional'. But business school faculty members, especially those in the more powerful departments such as finance who ignore both Knight and Barnard, seldom make this point.

The bottom line is that business schools lack even a single ToF on which they can mount a management-oriented curriculum or business model. The micro economists' ToFs clearly fail because they do not to provide either economists or managers with viable answers to Coase's questions. For managers, the bridge between theory and practice fails in two ways; first as it asserts generic answers to their challenges and ignores the indexicalities of their situation, and second it fails to shape the firm's activity towards its particular chosen ends. The current business school model pays little or no attention to the Knightian uncertainties present in the context of managerial work and so presumes generic answers. Other professions have few such aspirations - and focus their education on what practitioners do, and on the part played by the specifics uncertainties and resulting body of knowledge that shapes their profession's practice. Because business schools fail to identify the uncertainties managers actually deal with they cannot appeal to any similar body of knowledge or established professional practice. In the specialized areas of accounting and business law, of course, the uncertainties of title, valuation, and rights of use and exclusion are relatively well defined. Without a corresponding body of knowledge management cannot, as other profession do, police entry into the profession or their practice (Khurana 2007; Khurana and Nohria 2008). Business people must be found guilty of a crime before being debarred from practice, why Martha Stewart cannot now become a corporate officer even as her own firm remains in business. Many firms that have been bankrupt, such as GM, or have been charged with crimes, such as JP Morgan, remain in business.

To academics a ToF suggests something rigorous, perhaps validated empirically - though it is important to note that natural sciences theories are often held in high academic regard even when compelling empirical support is lacking: e.g. string theory or evolutionary theory. Practitioners, like architects or dentists, make less grand claims, more the heuristics revealed via considerable practice. A great deal of medical knowledge is of this form, so changes in these heuristics are events of considerable professional note, such as those produced by Semmelweis's research on the transmission of puerperal fever or the use of chloroform during child-birth. Medical and engineering research synthesizes theoretical ideas with training in these heuristics and their execution. A professional's attitude to theory comes from dealing with real world uncertainties whose theoretical categorization becomes central to the notion of professional practice - diagnosis. To be professional is to be able to bridge between the categorizing theory and experience of practice and arrive at a good diagnosis. Thus, a second reason why business cannot and should not be regarded as a profession is because these 
uncertainties are seldom admitted, let alone defined, considered, categorized, or brought into the curriculum's core. In these respects, law is interesting for there is no overarching theory of the law or legal practice; the natural law and legal realism traditions remain at loggerheads. The tension between them drives the field's academic theorizing and publishing forward. We cannot set up the same tension between our theory and our heuristics because our publishing practices prevent it.

A truly professional school approaches the gap between theory and practice from experience as well as from theory and it is not clear the agitation around 'evidence-based management' has been illuminating (Hodgkinson and Rousseau 2009; Pfeffer and Sutton 2006; Rousseau 2006; Rousseau and McCarthy 2007). Practice demands empirical generalizations be synthesized with the available theory without expecting either to be determining - for neither can provide all the inputs the professional needs for 'mindful' practice. Effective practice demands continuous awareness of failure. In this respect business educators might learn a great deal from the university's other professional schools' approaches, especially from art schools (Knight 1923; Spender 2005). Obviously, art focuses on the creation of some type of idiographic uniqueness, such as a painting, dance, or theatrical event. Some media presume repetition of what is unique, many performances of a specific play or piece of music, others do not presume this, such as painting or sculpture. The analogy is important because many see business as an art form, especially those following Knight's intuition that without uncertainty there can be economic activity, profit, or firms to manage (Knight 1923).

Firms' uniqueness puts question marks around what can be learned by comparing them. Another way of putting this is that if the essence of the manager's task is building an indexical bridge between what is known in general, such theory, and what is known specifically, such as practice under uncertainty, then comparing firms may not offer an appropriate methodology for advancing the manager's practice. At best it illuminates the general dimensions of the task, not the hard details which, as they say, lie with the Devil.

Historical and longitudinal methods focus on particulars and offer different insights. Engineers know how the history of bridge collapses illuminates which technological and theoretical advances were adopted and which rejected, a famous example being the Tacoma Falls suspension bridge collapse. Earthquake proofing is a major design constraint for bridges and buildings alike even though there is no theory of earthquakes or of their occurrence. The uncertainty is something professionals are able to deal with. Likewise Moore's Law illuminates the history of chip fabrication and is crucial to managers in many aspects of electronics design in spite of there being no 'theory'. Few schools pay attention to business or economic history as they encourage the 'harder' rigorous but a-historical research that characterizes our academic journals (Smith 2007; Fleet et al. 2005; Wright 2010). Nor are MBA students taught to study history as a mode of preparation for managerial practice - though many managers are attracted to history, perhaps as a reaction to its absence in their studies. When circumstances are uncertain historical methods can complement cross-sectional and statistical methods which are rendered less powerful than they would be under conditions of certainty and predictability.

Professional education, being oriented towards effective practice under uncertainty, calls for a methodological toolkit that differs from that of rigorous science. Simon's analysis highlighted the importance of Chicago style inter-disciplinary social science as a complement to mathematical rigor (Coase 1993). Methodological eclecticism offers mutually supporting bridges between cross-sectional and longitudinal methods, between methods that focus on what is general across a sample of comparables versus what is particular about an entity. The 
business school model is flawed if for one reason or another it fails to attend to the manager's need to construct such methodological bridges.

\section{Reconceptualizing the Business School}

Ironically the history of business schools offers us some guidance - provided we pay proper attention. In spite of what our industry's apologists suggest, the educational aim goes beyond filling out or extending the present theory-based model's curriculum with theories of corporate social responsibility or human motivation while keeping to the same methodologically rigorous agenda. As Bok's 1978 critique and writings have clarified, the business schools have successfully institutionalized quantitative methods while more or less delegitimizing the application of longitudinal methods (Spender 2012). The result is that business school students heading into management practice are not as well equipped those of the other professional schools, engineering, medicine, or art. MBAs are not well equipped to deal with the uncertainties of professional practice in the real world where to be a professional means to act mindfully and wisely within the real world's uncertainties - sick patients, collapsing bridges, or complex criminal cases.

Evolving management into a 'true profession' is not the same as equipping MBA students better for management practice; it needs an appropriate set of institutional structures, procedures, systems of evaluation and so on (Khurana 2007; Khurana and Nohria 2008; Metcalf 1927). In contrast, doctoral students are relatively well equipped for the practice they are to engage in - to do research and be faculty members (Spender and Khurana 2013). Business school doctoral students' difficulties are the same as the students of the true professions. Though perhaps fewer for other students' engagement with practice is greater and the theoretical implications of the constraints to practice carry more weight. Business school doctoral students get a clearer shot, able to focus on problems defined by the academic literature and overwhelmingly using large sample methods that wash out the indexicalities of the firms or managers in their sample. At the same time there is surprisingly little research into their particular difficulties when compared to the large volume of research into the challenges facing doctoral students in education, architecture, and engineering (Ehrenberg and Kuh 2009; Walker, Golde, Jones, Bueschel, and Hutchings 2008). Their greatest difficulties arise from the same 'equilibrating' tendencies Simon noted, the disparities between what we sometimes label 'silos'. When the school's faculty get into battles, especially manifest in the mutual disdain and methodological conflict between the finance and OB faculty, the student confronts what Hafferty dubbed the 'hidden agenda' of negotiating the school's contested political terrain (Hafferty 2002).

Many of the other professional schools coalesce around a mutually supporting set of theoretical and practical problems; the components that integrate into their intellectual signature' (Spender and Khurana 2013). The faculty in business schools is often widely separated in interest and method, and so researches very varied phenomena. Without the intellectual discipline of effective professional practice to guide the school's academic activity, 'entropy' rises and the Dean and administrators have more difficulty managing the intellectual terrain than do their colleagues in the other professional schools. For instance, among the US schools Babson's explicit focus on entrepreneurship makes for unusual clarity, as does NorthWestern's focus on executive education and as Thunderbird's on international business did likewise for a time. In the UK Lancaster's focus on leadership and LBS's focus on global 
business make their position clear. The Saïd School's growing focus on finance, like the Booth School's, might end up doing likewise provided the disenfranchised faculty members' resistance is quelled and the university leaves the school appropriate freedom (Kay 2000). These maneuvers manage entropy by narrowing the school's agenda but do not address how that agenda might be enriched methodologically and thereby changed to the MBA students' benefit. At the same time the growing trend towards specialized MBAs, with their explicit engagement with a defined context of managerial practice and its attendant uncertainties, heads in a different direction, ignoring the Barnardian synthesis that distinguishes CEO work from departmental management.

Must the general MBA go away, as 'general management' has gone away since the 1960s? General management's weakness was that it lacked theoretical underpinnings and, after the 1959 Foundation Reports, became academically unsupportable. It was often replaced by strategy, the AACSB's prescribed MBA 'capstone course' until the 1990s, what turned out to be a way-station towards the 'hard' positivist research dominance evident in today's $S M J$. In the process strategy underwent considerable change as it expanded and became a visible academic discipline; BPS is now among the Academy's largest divisions. Prior to the appearance of Porter's 5-forces analysis most school's way of teaching business strategy was dominated by the planning underpinnings of general management (Koontz 1964; M. E. Porter 1980; Spender and Kraaijenbrink 2011). Importantly HBS had a different approach that meshed with their case method, grounded in a series of 'blue book' strategy texts produced by a succession of HBS faculty that included Learned, Christensen, Andrews, Guth, and Bower (Learned, Christensen, Andrews, and Guth 1965). The classic problem - to find a 'sweet spot' between what the firm 'might do', 'wanted to do', 'could do', 'should do', and so specifically challenge the students' powers of judgment as well as of analysis. HBS students had to make judgments about the business's context, especially its competitive situation, and synthesize these with appropriate available theory. Barnard's notions were relevant though seldom mentioned. HBS intentionally focused on developing their MBA's judgment through a pedagogical practice that presumed managerial choice was seldom determined by theory alone, but required a synthesis with the implications of longitudinal methods (Christensen, Garvin, and Sweet 1991). HBS is also relatively unique in having a business history group that can balance its historical methods against the increasingly powerful tool-kit of quantitative methods offered in the other departments and in business schools generally.

\section{A Slightly Different Approach}

Just having a businessperson around the school cannot do much to ensure a synthesis-friendly mix of quantitative and longitudinal methods. Simon was somewhat coy in his 1967 paper but his thrust was towards helping students develop a degree of synthesizing competence, becoming to apply judgment to their entrepreneurial practice. His paper was written at a particularly pivot in his career (Spender 2013). Chicago trained, he arrived at Carnegie Mellon in 1949 to help build its business school from scratch, working with Lee Bach, a Chicago trained economist who was then the school's Dean, and Harold Guetzkow, a newly arrived Chicago trained social psychologist. All carried Chicago's multidisciplinary vision for social science and designed their school's initial MBA program accordingly. But as the school grew in size and stature it responded to changes going on in the social sciences generally and in business education in particular. These changes were formalized and promulgated through the 
Ford and Carnegie Foundations' 1959 reports (and the Foundations' subsequent funding), which, even though strongly shaped by Lee Bach and Donald David (Dean at HBS), shifted the business schools' agenda radically towards quantitative methods (Khurana 2007). The result, as we see today, is that doctoral students are no longer required to have substantive knowledge of any particular area of business, such as telecommunications, health-care, or aviation, but are required to show their competence with nomothetic quantitative methods. It is useful to recollect that HBS's initial curriculum dealt with specific industries such as railroading and insurance.

How can mixed quantitative and historical methods, plus careful attention to specific areas of business, lead to a more viable business school 'business model'? First, there is a trade-off between specialization, smaller numbers, versus the larger numbers resulting from the mainstream courses' claims of universality. Are business schools going to turn away students interested in specializing when their history shows claims to universality boost their growth while their inability to prepare students for managerial practice does not hinder them at all? Does the school's business model allow for core courses being broken up into the smaller class sizes associated with 'electives'? Even if the school's finances can stand it, will the faculty permit such changes when their institutional interests are precisely in the opposite direction? Second, will redesigning the school's program to present students with multiple methods as well as the contrast of theoretical generalizations and contextualizing particulars, meet the school's non-academic objectives? Even if good arguments can be made that such an approach would help develop the student's practical managing skills how might these be assessed? Interesting is the British tradition of 'sandwich' courses in which students spend some time in the academic setting and some in the business setting. The student's work in the firm is supervised by the firm's managers as well as by academics from the institution granting their degree. But sandwich courses are faculty intensive and notoriously difficult to manage and open to many conflicts of interest and misunderstanding. Plus the student's performance can only be evaluated subjectively. But managerial judgment is subjective too - and here we finally grasp the nettle.

\section{Language Games}

Academics know a great deal about the complexities and vicissitudes of evaluating scholarly work. While the conclusion may be an exercise of judgment it is typically against the background of a particular academic discipline that stands on particular axioms and is directed towards particular problematics. Awareness of all three shows how disciplines operate within a paradigm even though, as Kuhn argued; such paradigms often change, sometimes suddenly. Changes in academic paradigms parallel the importance of heuristic change for professionals. Indeed we might regard a discipline's axioms and problematics as its professional heuristics since they too are adopted as judgments and shape practice. Plus none can be unambiguously related to reality or falsified. So evaluating a academic's professional practice demands knowledge of and competence with the specific terminology and methodological and language practices that underpin that domain. Academics construct a language to help them abstract, back away from the indexicalities of practice into a region of generalities where their methods are more powerful, enough to generate theory. This 'language of necessity' follows as the discipline makes judgments about which axioms, problematics, and methods to consider and which to ignore. Some questions can be asked - such as "Why are there firms?" or "Why did Apple introduce the Newton?" Many other questions cannot be asked; "Why did Napoleon 
invade Russia?" or "Why did Ford introduce the Edsel?" Likewise a specific language is shared among those within the firm who are engaged in addressing the strategist's chosen questions - such as how is the firm going to respond to that particular competitor's move or should the firm buy its way into this particular market? Other questions - such as "Should the government raise corporate taxes?" or "Should the firm's local community close its primary school?" - cannot be asked in ways that relate to the firm's strategy, only as citizens beyond the firm might ask them. The ask-able and un-ask-able questions are located in separate 'language games'.

The work of managers differs from that of business school academics because their practices are located in dissimilar language games (Koppl and Langlois 2001). As professional schools respond to that profession's changing heuristics and practices overlaps develop. Medical researchers often use the same terms as their practitioner colleagues, with the same meanings. There are less obvious overlaps between business school academics and managers. Even when the terms are the same, such as 'firm' or 'profit' or 'capital' the academics' definitions differ radically from the managers'. Management practice itself is hung within contrasting language games, one of the propositions behind 'stakeholder theory'. Not all academics appreciate the term stakeholder does not imply a multi-player zero-sum game, a simple contest for a greater share of the spoils. Rather it presumes stakeholders differ and that each deploys a different language to capture their interests. Resolving the contrasts is then made difficult and beyond the reach of game theory, calling for contextualized judgment and powers of synthesis. Likewise the task of constructing bridges between theory and practice in business schools is difficult because their language games are so separated.

\section{Evaluation}

Under uncertainty, real markets require buyers ot evaluate sellers' offers and strategists have to evaluate specific alternative actions. Similarly, a school's business model is bound up with student evaluation. Students compete. But how are they evaluated, and can this be related to their prospects as business practitioners? Schools are quite content to measure a student's performance on, say, a finance exam or a strategy paper. All the students are graded similarly, against a single scale of correct answers. But we are not able to relate these grades to the overall educational impact on the student or forecast how the student's life chances have been changed. Grading is simply one part of the professional educator's practice, justified by tradition rather than by theory. Business is likewise competitive and bound up with evaluation. Firm performance can be evaluated by comparing earnings, growth, longevity and so on, using approved metrics that apply equally to all firms, a matter of tradition, government requirements, and the needs of investors.

But managers cannot be evaluated with these metrics despite much research into 'managerial quality' (Koch and Cabula 1994). Under real uncertainty it is almost never possible to evaluate a particular manager's contributions to the firm's performance, to isolate the impact of a particular team member (Alchian and Demsetz 1972). At the same time business school presumes the education provided has a payoff for students and/or their employers even as this cannot be evaluated - except in the long run when, as Keynes remarked, 'we are all dead'. Thus the school's design gravitates to grading because there are few alternative means of measurement given our culture demands students must be sorted into winners and losers. If a school was to focus on developing the students' judgment and synthesizing under uncertain circumstances, grading becomes progressively less relevant and more subjective. Is grading to 
be completely replaced by faculty members' recommendations based on personal knowledge, bias, and experience? In art school the aim is to develop one's own expressive technique, not to compete.

The last century's history shows a powerful society-wide trend towards quantitative modes of evaluation (T. M. Porter 1995). Few who criticize business schools for prioritizing quantitative methods pay attention to this trend, looking at the curriculum as an isolated phenomenon and presuming it is the outcome of power struggles within the school and/or between the disciplines. Some accuse economics of 'colonizing' the discussion of the business schools' traditional problematics - choosing markets, arranging production, administrative processes, strategizing, being socially responsible (Fine and Green 2000). But economics is only one of the academic language games made more powerful by the trend to quantification; though clearly they are on the right side of history. But if, as Knight and Coase both argued, uncertainty is the most fundamental axiom of the firm's existence as a value-creating language game, then the power and relevance of present-day economics is hugely weakened, as doubts about economists' understanding the 2008 financial collapse affirms. Language games and subjectivity are in, as Hayek predicted (Hayek 1945). Yet the work of non-traditional economists such as the subjectivist economists or Austrians such as Lachmann and Shackle is seldom discussed within business schools or our A-journals.

At this point it becomes clear once again that the real challenge with designing a business school arises from our not being sure what a firm is - as Coase indicated. We cannot even be sure whether a firm is a thing with the ontology most researchers presume - IBM and Taco Bell obviously exist, no? Or whether a firm is merely a contrived language, carefully shaped to engage a chosen set of uncertainties - as Microsoft talk obviously differs from Apple talk (Spender 2014). Business people, in contrast, obviously have a pretty good idea what their firm is because they speak its language and know what it means to be socialized into it; even when they are not able to express that knowing in language academics use or understand. Few business school academics seem willing to admit this knowledge-absence. As a profession we seem to have agreed to press on regardless, educating increasing numbers of students in the languages only we academics know, even as we admit our inability to capture the uncertainties and phenomena with which managers must deal. We can look to the HBS tradition for pointers about the nature of the firm and how that might shape a school's design without denying the possibility that the HBS business model is as flawed as any other, but in its own way. The focus on case-work and synthesis shows that HBS regards the firm as a language constructed to identify some business uncertainties and how they should be dealt with. But this focus on developing the student's judgment means they are not able to grade their student's work quantitatively - or rather they are driven to grade on the student's performance in the languageintensive context of the case room.

\section{Each Firm's Uniqueness}

The proposition that every firm can be understood as an idiosyncratic local language that points to what must be considered and how that should shape practice - shows the central place of uncertainty and managerial judgment in its formation and activity. Firms are unique to the extent they engage specific contextual uncertainties with different judgments. This does not prevent them being similar in the assets or tools they acquire, such as land, labor, and capital, just as a Ferrari and a Ford use gas from the same pump. Tools never determine the firm's activities, even when relevant, and not all tools are relevant to all businesses. They merely 
constrain a firm's strategic options. Penrose pointed to the language differences between the economists' talk of resources and the management team's rent-seeking as it evaluated the services the resources provided their firm - the translation bridge being the team's knowledge, shared in their language (Penrose 1995).

Shifting the focus from (a) theorizing or (b) bridging the theory-practice gap to (c) the firm as an idiosyncratic language that shapes the participants' practice, redefines the management task. Presuming uncertainty is fundamental to the firm's existence, managers construct and use a 'local language' to engage the specific uncertainties they choose, whose successful engagement leads on the economic value-creation and profit. There are two complementary steps (Spender 2014; Spender and Strong 2014). First, the 'entrepreneurial idea' must be nailed down in language; second, the resulting language can be used to engage the judgments of the others needed. The second leverages the entrepreneur's initiating judgment into areas in which $\mathrm{s} /$ he has none. There is a division of judgment that complements the division of labor. Thus Henry Ford harnessed the knowledge, skills, and judgments of many others - designers, production engineers, and logistical and financial professionals - to transforming his entrepreneurial vision into his firm's productive practices. Clearly the production line was designed to minimize his dependence on the knowledge, skills and judgment of the assemblers - whose work was thereby considered 'dehumanized' because the exercise of judgment is as fundamental to the human condition as language. Ford's assemblers had no need to talk - but discussion between the professionals on whom Ford depended was crucial. Steve Jobs leveraged the judgments of a wide variety of professionals into executing his vision, something he was unable to do alone. Orr has shown the critical place of talk for industrial specialists (Orr 1996). The implication is that the firm is both an apparatus for setting up the division of labor, as Adam Smith told us, but also an apparatus for synthesizing the judgments necessary to articulate an entrepreneurial idea into coherent practice. Thus the answers to Coase's questions turn on the judgments that underpin the firm as a functioning language. These judgments are indexical, particular not generic - they deny the generic ToF many economists and management academics seek.

\section{Rhetoric}

At this point considering a firm as a special language may offer a better basis for a business school curriculum than any rigorous theorizing provides. Managing begins with creating a vision, but must be followed by the creation and application of the specific language that enables others to support that vision. Art schools encourage 'envisioning' by exposing students to constraints to their imagination and imaginings, not by dictating their thinking. Art is contextualized language also, and students learn it as they learn how their chosen medium constrains their vision and enables them to interpret what other artists are doing. They discover experientially what the language chosen cannot do, what cannot be expressed. They also learn about art by studying the history of what art is and what it is not. They learn about others' work via art criticism. Along these lines business school students might be taught how to articulate an entrepreneurial vision by discovering the constraints to their entrepreneurial imagination (Spender 2005, 2014). Many businesses, like artists, engage physical materials and too often we presume technological change determines entrepreneurial possibilities (Spender 2010). Yes, microchip development turns on the ability to engineer more transistors into a given space and deal with the increased heat produced, and, yes, many businesses deal with constraints on consumption, and all firms are constrained by corporate laws and regulations. But, as Penrose 
taught, language always stands between such 'facts' and their strategic impact on the firm. Empirical research into real business models suggests that most firms' languages are constructed from a dozen or so constraints, some more malleable than others (Spender 1989). To illustrate; the primary purpose of lobbying is to change the current legal or political constraints to the firm's strategic options, just as R\&D often focuses on moving the material and technological constraints to the entrepreneur's vision - especially obvious in Apple's case.

This focus on the firm as an idiosyncratic language suggests an entirely novel convergence of interest between academics and managers. Managers might learn more about how to construct and use a specific language and then become skilled rhetoricians, able to persuade skilled others to 'get with the program'. Academics know plenty about how specific languages are constructed, their capacity and limits (Weisler and Milekic 1999). They are always bounded by their axioms, so languages differ because their axioms differ. Note that Chomsky's assertion of a 'universal grammar' is of no relevance, given we can never escape our language to observe or test the assertion. We are permanently imprisoned in our languages for, as far as we know, there is no language that can grasp the entirety of the human condition and experience. Language is a practical concept, always limited and 'bounded' - as is our rationality. Managers build the firm's own language by selecting the specific constraints they find relevant to the context in which they seek economic value and 'axiomatizing' them. The most popular strategic tool, SWOT, constructs a simple language for grasping the firm's situation. There are many other languages, such as the Balanced Scorecard or that implicit in the BCG matrix. Each is appropriate to a different conception of the strategic situation and challenge. In contrast, most economists presume universal constraints and articulate them into a one-dimensional academic discourse that spins on money. Linguists know there is a huge number of languages, some managerial (Anderson 2012). One view of philosophers' work is that it is about 'purifying' everyday language and so advancing our capacity to grasp the human condition. From this viewpoint managing is applied philosophizing, and academics can usefully bring their methodological tools to bear on that. 'Critical thinking' educators try to encourage in their students' creativity, complementing improving their analytic competence. In business schools the closest most MBAs get to critical thinking is in the case room where individual students confront the same facts as their colleagues and compete to generate more insightful or persuasive meanings and discussion.

For millennia teachers of rhetoric regarded training and skills with language as essential for leaders. The trivium comprises grammar, logic, and rhetoric. While the business schools are strong on logic they pass over grammar and rhetoric as if they are of no account, unworthy of academic attention (Sayers 1947). Yet firms are social situations embedded in other social and political situations, unified by rhetorical practices. Since logic alone cannot explain firms' existence or guide their process they might be better conceptualized as situations of rhetorical persuasion rather than of analysis. The implication is that rhetoric should be restored to core the MBA curriculum. Managing is, after all, a talking game. Our students deserve a discussion of rhetorical theories and heuristics. Practice in persuasion in the case room's essence. Thus managing is a form of theater, artful persuasion in which the language of numbers and data may play a role, but cannot ever compel conclusions. Rhetoric embraces quantitative methods ( $\log o s)$ but reaches beyond them to modes of persuasion that turn on character and history (ethos) and on emotion (pathos) (Conley 1990).

Fortunately, a great deal is known about how to teach rhetoric, there is no need to invent new topics or pedagogy, though the stubbornness of computer-mediated communication makes an on-line course on rhetoric a stretch. It is not clear that a MOOC could ever help 
students achieve rhetorical competence. But the case room is just the place - no right answer and a bevy of bright, attentive, and critical audience members. Rhetoric was a competitive activity in Ancient Greece and Medieval Europe. The history of rhetoric also suggests that while there is a social trend to numbers as a preferred mode of persuasion, logos alone has never been sufficient to the rhetor's challenge to persuade other people to act towards her/his goals. The complaint against quantification cannot be dealt with by having less of it especially in the age of 'big data' and full time monitoring. Rhetoric shows the challenge of communicating effectively with human beings always requires logos to be complemented - to draw listeners across the bridge between theory and committed practice. Persuasive communication, the art of the deal, is the managerial medium and can be taught in business schools just as art, or engineering or medicine, can be taught in those professions' schools. No expensive physical changes are required; just a change of mindset from the application of determining theories to the creative practice of engaging uncertainty. In which event many of the impediments and difficulties that Simon analyzed dissolve. As the irrelevance of analysis alone to the pursuit of profit becomes clear, his dichotomy collapses. All departments can collaborate. In this sense organizational design becomes a 'non-problem'. Only the divergence of interest between career-building academics and competence-seeking students remains to challenge the Dean. She/he needs the rhetorical competence to overcome the divisions of labor and judgment and persuade all parties into collaborative activity. Each has to give a little.

\section{Concluding Comment}

The implications for the design of a business school are clear. If managing is persuasion that leverages from but is not determined by rigorous decision-making we business educators would do well to complement our increasing powers of analysis with new attention to the manager's ultimate objective - the persuasion of others. Rhetoric was pushed out of the university curriculum in the $19^{\text {th }}$ century as educators became persuaded that the methods of the natural sciences could/should be applied to the social sciences in general and business in particular. Curiously the history of the decline of rhetorical studies mirrors the rise of business schools and of rigorous methods. But rhetoric (and the powers of judgment it fosters) cannot be taught as theory, for the activities are ultimately indexical and can only be grasped tacitly, as practice. They can only be learned as we learn to ride a bicycle. Business schools that use the case method may be creating the pedagogical spaces necessary for students to learn by 'speaking out' to their peers, a bit different from the normal Socratic approach, but depend on the same mechanisms to convince students to think about what they intend to say, to synthesize what they know into something relevant to the context being discussed, and to be persuasive. Many experienced managers - some of whom might have studied rhetoric and discovered its immense power - harness the capacities of others as they bring their firm into existence as a collaborative practice of value-creation. The result is hugely more powerful than the entrepreneur on her/his own.

Which leads to a caution. Rhetoric has a central place in value creation, drawing in whatever theory is judged relevant, along with heuristics, hunches, inspirations, insights, and emotions. But it may become suppressed where creativity is unwelcome. We know firms are loci of value-creation; it is their raison d'être. But not all parts of the economy create value; some are more focused in value capture (Priem et al. 2013). Monopolies may extract value rather than add it. Some parts of the financial services industry may not add much any value, 
profiting as they redistribute value. Many scholars have observed the increasing 'financialization' of our economy (Krippner 2005; Lazonick and O'Sullivan 2000). If we are training MBAs for such work analysis may be all they require, rhetoric and critical thinking may find no place in their tool kit.

Open Access This article is distributed under the terms of the Creative Commons Attribution 4.0 International License (http://creativecommons.org/licenses/by/4.0/), which permits unrestricted use, distribution, and reproduction in any medium, provided you give appropriate credit to the original author(s) and the source, provide a link to the Creative Commons license, and indicate if changes were made.

\section{References}

AACSB. (2013). Business School Data Trends. Retrieved from Tampa Florida.

Alchian, A.A., and H. Demsetz. 1972. Production, information costs, and economic organization. American Economic Review 62(5): 777-795.

Anderson, S.R. 2012. Languages: A Very Short Introduction. Oxford: Oxford University Press.

Barnard, C.I. 1951. The Functions of the Executive. Cambridge: Harvard University Press.

Bewley, T.F. 1998. Knightian Uncertainty. In Frontiers of Research in Economic Theory, ed. D. Jacobs, E. Kalai, and M. Kamien, 71-81. New York: Cambridge University Press.

Bok, D.C. 1978. The President's Report 1977-1978. Cambridge: Harvard University.

Boudreaux, D.J., and R.G. Holcombe. 1989. The coasian and knightian theories of the firm. Managerial and Decision Economics 10(2): 147-154.

Byrne, J. A. (2013). Business School is a Waste ... if You Want to Blow $\$ 100 \mathrm{~K}$, Go to Vegas. Retrieved from http://poetsandquants.com/2013/10/10/bragging-rights-whose-mbas-make-the-most/.

Carrington Crisp. (2013). The New Diversity: Tomorrow's MBA: Executive Summary. Retrieved from London.

Christensen, C.R., D.A. Garvin, and A. Sweet. 1991. Education for Judgment: The Artistry of Discussion Leadership. Boston: Harvard Business School Press.

Coase, R.H. 1991. The Nature of the Firm (1937). In The Nature of the Firm; Origins, Evolution and Development, ed. O.E. Williamson and S.G. Winter, 18-33. New York: Oxford University Press.

Coase, R. H. (1993). Law and Economics at Chicago. Journal of Law and Economics, 36(No. 1, Part 2, John M. Olin Centennial Conference in Law and Economics at the University of Chicago (Apr.,)), 239-254.

Coase, R.H., and N. Wang. 2012. Saving economics from the economists. Harvard Business Review 90(12): 36.

Conley, T.M. 1990. Rhetoric in the European Tradition. Chicago: University of Chicago Press.

Currie, G., D. Knights, and K. Starkey. 2010. Introduction: a post-crisis critical reflection on business schools. British Journal of Management 21(1): S1-S5.

Datar, S.M., D.A. Garvin, and P.G. Cullen. 2010. Rethinking the MBA: Business Education at a Crossroads. Boston: Harvard Business Press.

Demsetz, H. 1988. The theory of the firm revisited. Journal of Law, Economics, and Organization 4: 141-161.

Durand, T., and S. Dameron (eds.). 2008. The Future of Business Schools: Scenarios and Strategies for 2020. Basingstoke: Palgrave Macmillan.

Ehrenberg, R.G., and C.V. Kuh (eds.). 2009. Doctoral Education and the Faculty of the Future. Ithaca: Cornell University Press.

Fine, B., and F. Green. 2000. Economics, Social Capital, and the Colonization of the Social Sciences. In Social Capital: Critical Perspectives, ed. S. Baron, J. Field, and T. Schuller, 78-93. Oxford: Oxford University Press.

Fleet, V., D. David, and D.A. Wren. 2005. Teaching history in business schools: 1982-2003. Academy of Management Learning \& Education 4(1): 44-56.

Fragueiro, F., and H. Thomas. 2011. Strategic Leadership in the Business School: Keeping One Step Ahead. Cambridge: Cambridge University Press.

GMAC. (2013). Application Trends Survey: Survery Report. Retrieved from Reston VA.

GMAC (Ed.) (2013). Disrupt or Be Disrupted: A Blueprint for Change in Management Education. San Francisco CA: Jossey-Bass.

Grey, C. (2004). Reinventing Business Schools: The Contribution of Critical Management Education Academy of Management Learning \& Education (Vol. 3, pp. 178): Academy of Management.

Hafferty, F.W. 2002. What medical students know about professionalism. Mount Sinai Journal of Medicine 69(6): 385-397. 
Hardy, G.M., and D.L. Everett (eds.). 2013. Shaping the Future of Business Education: Relevance, Rigor, and Life Preparation. Basingstoke: Palgrave Macmillan.

Hayek, F.A. 1945. The use of knowledge in society. American Economic Review 35(4): 519-530.

Hodgkinson, G.P., and D.M. Rousseau. 2009. Bridging the rigour-relevance gap in management research: it's already happening! Journal of Management Studies 46(3): 534-546.

Jaiswal, A. (2015). How to Reform a Business School - The Ivy League Way: Theory and Practice of Curricular Reform Implementation with an in-Depth Study of Yale School of Management. Oxford: Oxford Centre for Higher Education Policy Studies (OXCHEPS).

Kay, J. (2000). A Lost Cause? Retrieved from http://www.johnkay.com/2000/12/20/a-lost-cause.

Khurana, R. 2007. From Higher Aims to Hired Hands: The Social Transformation of American Business Schools and the Unfulfilled Promise of Management as a Profession. Princeton: Princeton University Press.

Khurana, R., and N. Nohria. 2008. It is time to make management a true profession. Harvard Business Review 86(10): 70-77.

Khurana, R., and J.-C. Spender. 2012. Herbert A. Simon on what ails business schools: more than 'A problem in organizational design'. Journal of Management Studies 49(3): 619-639.

Klein, J.T. 1990. Interdisciplinarity: History, Theory, and Practice. Detroit: Wayne State Univesity Press.

Knight, F.H. 1921. Risk, Uncertainty and Profit. Boston: Houghton Mifflin Company.

Knight, F.H. 1923. Business management: science or art? Journal of Business 2(4): 5-24.

Koch, J., and R.J. Cabula. 1994. In search of excellent management. Journal of Management Studies 31: 681-699.

Koontz, H. 1964. Toward a Unified Theory of Management. New York: McGraw-Hill.

Koppl, R., and R.N. Langlois. 2001. Organizations and language games. Journal of Management \& Governance 5(3/4): 287-305.

Krippner, G.R. 2005. The financialization of the American economy. Socio-Economic Review 3(2): 173-208.

Lazonick, W., and M. O'Sullivan. 2000. Maximizing shareholder value: a new ideology for corporate governance. Economy \& Society 29(1): 13-35.

Learned, E.P., R. Christensen, K. Andrews, and W. Guth. 1965. Business Policy: Text and Cases. Homewood: Richard D. Irwin.

Locke, R.R., and J.-C. Spender. 2011. Confronting Managerialism: How the Business Elite and Their Schools Threw Our Lives Out of Balance. London: Zed Books.

Lorange, P. 2008. Thought Leadership Meets Business: How Business Schools Can Become More Successful. Cambridge: Cambridge University Press.

Magretta, J. 2002. Why business models matter. Harvard Business Review 80(5): 86-92.

Medema, S.G. 1995. Ronald coase on economics and economic method. History of Economic Review 24: 1-22.

Metcalf, H.C. (ed.). 1927. Business Management as a Profession. Chicago: A. W. Shaw Company.

Mintzberg, H. 2004. Managers not MBAs: A Hard Look at the Soft Practice of Managing and Management Development. San Francisco: Berrett-Koehler Publishers.

Mintzberg, H. 2013. Simply Managing: What Mangers Can Do - and Can Do Better. San Francisco: BerrettKoehler.

Moore, E.C. (ed.). 1972. Charles S. Peirce: The Essential Writings. New York: Harper \& Row.

Morsing, M., and A. Sauquet (eds.). 2011. Business Schools and Their Contribution to Society. London: Sage Publications.

Muff, K., T. Dyllick, M. Drewell, J. North, P. Shrivastava, and J. Haertle. 2013. Management Education for the World: a Vision for Business Schools Serving People and Planet. Cheltenham: Edward Elgar.

Orr, J.E. 1996. Talking about Machines: An Ethnography of a Modern Job. Ithaca: ILR Press.

Parker, M. 2002. Against Management. Cambridge: Polity Press.

Penrose, E.T. 1995. The Theory of the Growth of the Firm, 3rd ed. New York: Oxford University Press.

Peters, K., and M. Gitsham. 2009. Developing the global leaders of tomorrow. EFMD Global Focus 3(1): 58-61.

Pfeffer, J., and R.I. Sutton. 2000. The Knowing-Doing Gap: How Smart Companies Turn Knowledge into Action. Boston: Harvard Business School Press.

Pfeffer, J., and R.I. Sutton. 2006. Evidence-based management. Harvard Business Review 84(1): 63-74.

Porter, M.E. 1980. Competitive Strategy: Techniques for Analyzing Industries and Competitors. New York: Free Press.

Porter, T.M. 1995. Trust in Numbers: The Pursuit of Objectivity in Science and Public Life. Princeton: Princeton University Press.

Priem, R.L., J.E. Butler, and S. Li. 2013. Toward reimagining strategy research: retrospection and propsection on the 2011 AMR decade award article. Academy of Management Review 38(4): 471-489.

Rousseau, D.M. 2006. Is there such a thing as evidence-based management? Academy of Management Review 31(2): 256-269.

Rousseau, D.M., and S. McCarthy. 2007. Educating managers from an evidence-based perspective. Academy of Management Learning \& Education 6(1): 84-101. 
Sayers, D.L. 1947. The lost tools of learning. Quartley Review of Religion, Theology, and Philosophy 46: 1-20.

Scheffler, I. 1974. Four Pragmatists: A Critical Introduction to Peirce, James, Mead, and Dewey. London: Routledge \& Kegan Paul.

Silverstein, A. 1988. An aristotelian resolution of the idiographic versus nomothetic tension. American Psychologist 43(6): 425-430.

Simon, H.A. 1967. The business school: a problem in organizational design. Journal of Management Studies 4(1): 1-16.

Smith, G.E. 2007. Management history and historical context: potential benefits of its inclusion in the management curriculum. Academy of Management Learning \& Education 6(4): 522-533.

Spender, J.-C. 1989. Industry Recipes: The Nature and Sources of Managerial Judgement. Oxford: Blackwell.

Spender, J.-C. 2005. Speaking about management education: some history of the search for legitimacy and the ownership and control of management knowledge. Management Decision incorporating the Journal of Management History 43(10): 1282-1292.

Spender, J.-C. 2007. Management as a regulated profession: an essay. Journal of Management Inquiry 16(1): 3242.

Spender, J.-C. 2008. The Business School in America: A Century Goes By. In The Future of Business Schools: Scenarios and Strategies for 2020, ed. T. Durand and S. Dameron, 9-18. Basingstoke: Palgrave Macmillan.

Spender, J.-C. 2010. Technology: Discourse and Possibility. In Encyclopedia of Technology and Innovation Management, ed. V.K. Narayanan and G.C. O'Connor, 3-8. Chichester: Wiley.

Spender, J.-C. 2011. Human Capital and Agency Theory. In The Oxford Handbook of Human Capital, ed. A. Burton-Jones and J.-C. Spender, 186-217. Oxford: Oxford University Press.

Spender, J.-C. (2012). The Quants Impact on Management Education and What We Might Do About It: A History Framed Essay on Rethinking the MBA Program. ESADE Working Paper No.228.

Spender, J.-C. 2013. Herbert Alexander Simon: Philosopher of the Organizational Life-World. In Oxford Handbook of Management Thinkers, ed. M. Witzel and M. Warner, 297-357. Oxford: Oxford University Press.

Spender, J.-C. 2014. Business Strategy: Managing Uncertainty, Opportunity, and Enterprise. Oxford: Oxford University Press.

Spender, J.-C., and R. Khurana. 2013. Intellectual Signatures: Impact on Relevance and Doctoral Programs. In Disrupt or Be Disrupted: A Blueprint for Change in Management Education, ed. G.M.A. Council, 131-177. San Francisco: Jossey-Bass.

Spender, J.-C., and J. Kraaijenbrink. 2011. Why Competitive Strategy Succeeds - and With Whom. In Competition, Competitive Advantage, and Clusters: The Ideas of Michael Porter, ed. R. Huggins and $\mathrm{H}$. Izushi, 33-55. Oxford: Oxford University Press.

Spender, J.-C., and B. Strong. 2014. Strategic Conversations: Creating and Directing the Entrepreneurial Workforce. Cambridge: Cambridge University Press.

Starkey, K., \& Tempest, S. 2001. The World-Class Business School: A UK Perspective. Retrieved from London.

Starkey, K., and N. Tiratsoo. 2007. The Business School and the Bottom Line. Cambridge: Cambridge University Press.

Tsoukas, H., and N. Mylonopoulos (eds.). 2004. Organizations as Knowledge Systems: Knowledge, Learning and Dynamic Capabilities. Basingstoke Hants: Palgrave Macmillan.

Walker, G.E., C.M. Golde, L. Jones, A.C. Bueschel, and P. Hutchings. 2008. The Formation of Scholars: Rethinking Doctoral Education for the Twenty-First Century. Stanford: Carnegie Foundation.

Weisler, S.E., and S. Milekic. 1999. Theory of Language. Boston: MIT Press.

Wright, R.E. 2010. Teaching history in business schools: an insiders view. Academy of Management Learning \& Education 9(4): 697-700. 